\title{
YOUTUBE SEBAGAI MEDIA DAKWAH MASA PANDEMI COVID 19 (Studi Analisis Konten Dakwah Channel Muslimah Media Center 15-30 Juni 2020)
}

\author{
Farida Nur Rahma1, Mada Wijaya Kusumah'2 \\ ${ }^{1}$ Pendidikan Bahasa Arab, STIBA Ar Raayah, Indonesia \\ ${ }^{2}$ Komunikasi dan Penyiaran, STIBA Ar Raayah, Indonesia \\ *assumedangi@gmail.com \\ *madawijayakusumah@gmail.com
}

\begin{abstract}
Abstrak
Protokol Kesehatan masa pandemi Covid 19 mengharuskan masyarakat menjaga jarak bahkan berdiam diri di rumah. Ini membuat kerja, transaksi, belajar bahkan dakwah dilakukan di rumah. Berbagai aplikasi media sosial sebagai jembatannya. Sehingga, tujuan penelitian ini adalah menganalisis konten dakwah dari channel Youtube Muslimah Media Center selama bulan Juni 2020. Metode yang digunakan adalah metode kualitatif. Pendemi Covid 19 tidak membuat dakwah terhenti karena perkembangan teknologi media sosial menyediakan berbagai aplikasi. Youtube sebagai aplikasi media social yang paling banyak diakses menjadi peluang besar. Hal ini disadari oleh berbagai kanal dakwah Youtube termasuk kanal dakwah Muslimah Media Center (MMC). Adapun konten dakwah MMC sangat produktif dan unik. Produktif karena selain frekuensi posting yang tinggi setiap hari, juga mengangkat tema-tema dari masalah yang sedang hangat. Baik tentang politik, ekonomi, social, kesehatan terutama penanganan pandemic covid 19, pendidikan maupun remaja. Konten disajikan dengan sebuah kerangka berpikir bahwa berbagai permasalahan yang terjadi akibat pengaturan kapitalisme yang keliru. Selalu diakhiri dengan seruan untuk kembali pada aturan atau sistem atau ideology Islam sebagai solusi bagi setiap permasalahan.
\end{abstract}

Kata kunci : Dakwah; Youtube; Pandemi

\begin{abstract}
The Covid 19 pandemic health protocol requires that people keep their distance and even stay at home. This makes work, transactions, learning and even preaching done at home. Various social media applications as a bridge. Thus, the purpose of this study is to analyze the da'wah content of the Muslimah Media Center Youtube channel during June 2020. The method used is a qualitative method. Pendvid Covid 19 did not stop the da'wah because the development of social media technology provides various applications. Youtube as the most accessed social media application becomes a big opportunity. This is realized by various dakwah channels on Youtube including the Muslimah Media Center (MMC) channel. The $M M C$ propaganda content is very productive and unique. Productive because in addition to the high frequency of posting every day, it also raises the themes of the current problem. Good about politics, economics, social, health, especially handling the 19th pandemic, education and youth. Content is presented with a framework of thinking that the various problems that occur due to the wrong arrangement of capitalism. It always ends with a call to return to the rules or systems or ideology of Islam as a solution to every problem.
\end{abstract}

Keywords: Da'wah; Youtube; Covid 19 


\section{Pendahuluan}

15 Maret 2020 pemerintah Indonesia memberlakukan sosial distancing. Hal tersebut dalam rangka melindungi masyarakat dari infeksi virus Corona ${ }^{1}$. Kebijakan sosial distancing menyebabkan terbatasnya berbagai aktifitas diberbagai bidang kehidupan, mulai dari aktifitas ekonomi (industry, pertambangan, pertanian, perkebunan, perdagangan ekspor maupun impor) sosial, kebudayaan dan pariwisata, pendidikan, pelayanan umum sampai syiar agama. Sebagian besar aktifitas dilakukan dari rumah sehingga muncul istilah Work from Home (WFH), School from Home (SFH) atau Belajar Dari Rumah (BDR) sampai Dakwah Dari Rumah .

Media sosial menjadi sarana publikasi aktifitas yang dilakukan dari rumah. Adapun media sosial yang banyak digunakan adalah youtube, whatsapp, facebook, instagram, tiktok, line, tweeter, reddit, pinterest dan tumblr ${ }^{2}$. Seperti yang lansir merdeka.com, bahwa berdasarkan data We Are Sosial, 88\% pengguna media sosial Indonesia menggunakan atau mengakses youtube.

Peluang besar yang ada pada youtube dimanfaatkan sejumlah youtuber untuk mendulang subscriber. Termasuk para da'i atau mubaligh baik personal maupun lembaga dakwah. Salah satu channel yang menonjol adalah Muslimah Media Center. Menonjol karena mereka mengupload hampir tiap hari dengan tema politik, ekonomi, pendidikan sampai tema remaja.

Penelitian terhadap youtube sebagai media sosial banyak, begitu juga tema penelitian youtube sebagai media sosialisasi dakwah Islam. Namun, peneliti melihat masih umumnya pembahasan pada penelitian tersebut. Ada penelitian yang hampir sama focus kajiannya pada konten dakwah tapi tetap berbeda pada objek penelitiannya. Peneliti merinci objek bahasan pada satu kanal dakwah tertentu yaitu Muslimah Media Center.

Media Center memiliki tema kajian unik. Berbeda dengan tema kajian kanal media dakwah lain seputar aqidah, fiqih ibadah, parenting islam, Al-Quran dan akhlak. Muslimah Media Center dihiasi dengan content fakta, analisis dan solusi atas permasalahan factual negara baik bidang politik, ekonomi, sosial sampai tema remaja.

Sehingga, peneliti akan menganalisis tema dakwah kanal youtube Muslimah Media Center pada masa pandemi covid 19 khususnya bulan Juni 2020. Sehingga akan terlihat, kekhasan apa yang dimiliki dan hal baru yang bisa menjadi sumber inspirasi baru bagi kanal dakwah lain.

\footnotetext{
${ }^{1}$ Larassaty, Levi. 2020. Pemerintah Memberlakukan Sosial Distancing. Apa Itu Sosial Distancing ? , diakses 10 Juli 2020.

https://health.grid.id/read/352064010/pemerintah-memberlakukan-sosial-distancing-apa-itu-sosial-distancing?page=all ${ }^{2}$ Widyananda, Rakha Fahreza. 2020. Macam Media Sosial yang Paling Sering Digunakan Oleh Orang Indonesia. Diakses 10 Juli 2020. https://www.merdeka.com/iatim/10-macam-media-sosial-yang-paling-sering-digunakan-oleh-orang-indonesia-kln.html
} 


\section{Metode Penelitian}

Metode penelitian yang digunakan adalah metode penelitian kualitatif dengan pendekatan studi literatur dan bersifat deskripsi analisis. Objek penelitian diamati secara virtual. Penelitian yang bertujuan untuk memahami fenomena lebih mendalam, karena fokus pada satu objek bahasan dengan paparan analisis proses dan makna terhadap objek pembahasan tertentu.

Penelitian ini akan fokus membahas dan menganalisis konten dakwah kanal Muslimah Media Center khususnya video dakwah yang tayang di bulan Juni 2020. Muslimah Media Center [MMC] adalah media Islam yang memiliki komitmen untuk bisa memberikan analisa terhadap masalah-masalah khususnya di Indonesia dan dunia Islam dengan menghadirkan Islam sebagai solusi praktis dan efektif. ${ }^{3}$ Kanal Muslimah Media Center bisa diakses dengan alamat https://www.youtube.com/channel/UCgQBZ25YtD cm8hpCsey67w/. Kanal ini memiliki moto "Insprasi Muslimah Masa Kini". Adapun sasaran penggemarnya yaitu remaja, ibu dan perempuan. Total yang menyukai kanal ini adalah 12.101. Sedangkan, pengikutnya mencapai $12.788 .{ }^{4}$

Peneliti mengamati video yang di post Muslimah Media Center mulai dari 15 - 30 Juni 2020. Video yang di post akan di klasifikan dalam bentuk tabel berdasarkan tema konten. Sehingga akan terlihat konten yang sering dibahas, keunggulan konten, kelemahan konten, tujuan umum dari konten yang di post dan kesesuaian konten dengan target penggemar.

\section{Hasil dan PEMbahasan}

\section{A. Akses Media Sosial Masa Pandemi Covid 19}

30 Juni 2020 Gugus Tugas Penanganan Covid 19 menyatakan kasus terkonfirmasi positif corona telah mencapai angka 56.385 pasien. Mengalami penambahan sebanyak 1.293 kasus, bila dibandingkan data terakhir pada hari sebelumnya. Jawa Timur menjadi provinsi dengan kasus positif Covid 19 tertinggi di Indonesia melampaui DKI Jakarta. ${ }^{5}$

\footnotetext{
${ }^{3}$ Youtube Muslimah Media Center. Diakses tanggal 10 Juli 2020. https://www.youtube.com/c/MUSLIMAHMEDIACENTERID/about

${ }^{4}$ Facebook Muslimah Media Center. Diakses tanggal 10 Juli 2020.

https://www.facebook.com/pg/MuslimahMediaCenter/posts/?ref=page internal

${ }^{5}$ Fatoni, Muhammad. 2020. Peta Sebaran Covid-19 di Indonesia Selasa 30 Juni 2020 Petang Ini, Data Rincian Kasus di 34 Provinsi. Diakses tanggal 10 Juli 2020.

https://jogja.tribunnews.com/2020/06/30/peta-sebaran-covid-19-di-indonesia-selasa-30-juni-2020-petang-ini-datarincian-kasus-di-34-provinsi
} 


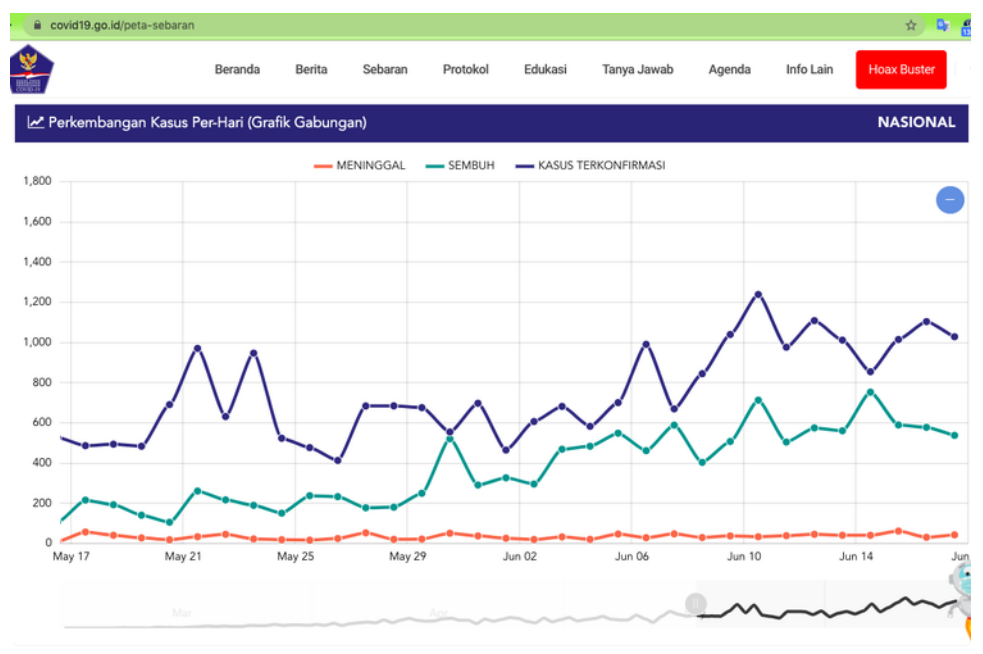

Sumber: Kompas.com - 17/06/2020

Grafik 1 Perkembangan Kasus Covid 19 Bulan Juni6

Upaya yang telah dilakukan pemerintah salah satunya adalah memberlakukan sosial distancing pada 15 Maret $2020 .{ }^{7}$ Hal tersebut dalam rangka melindungi masyarakat dari infeksi virus Corona. Kebijakan sosial distancing menyebabkan terbatasnya berbagai aktifitas diberbagai bidang kehidupan, mulai dari aktifitas ekonomi (industry, pertambangan, pertanian, perkebunan, perdagangan ekspor maupun impor) sosial, kebudayaan dan pariwisata, pendidikan, pelayanan umum sampai syiar agama. Sebagian besar aktifitas dilakukan dari rumah sehingga muncul istilah Work from Home (WFH), School from Home (SFH) atau Belajar Dari Rumah (BDR) sampai Dakwah Dari Rumah .

Media sosial menjadi sarana publikasi aktifitas yang dilakukan dari rumah. Adapun media sosial yang banyak digunakan adalah youtube, whatsapp, facebook, instagram, tiktok, line, tweeter, reddit, pinterest dan tumblr ${ }^{8}$ (merdeka.com, 4/6/2020). Secara umum, selama kuartal 1 2020, Sensor Tower melaporkan, konsumsi data untuk mengunduh aplikasi mobile meningkat hingga mencapai 596 petabyte atau 596 juta gigabyte. Meningkat 34 persen jika dibanding periode yang sama tahun lalu. Jika dibanding kuartal-I dalam tiga tahun terakhir, kenaikannya mencapai 52 persen dari rata-rata konsumsi data sebesar 391 petabyte. Adapun aplikasi media sosial yang paling banyak diakses atau diunduh menurut data We Are Sosial adalah Youtube. ${ }^{9}$

\footnotetext{
${ }^{6}$ Azanella, Luthfia Ayu. 2020. Tren Kasus Covid 19 Meningkat di Buan Juni, Ini Aklasannya Menurut Ahli . Diakses 10 Juli 2020. https://www.kompas.com/tren/read/2020/06/17/200500665/tren-kasus-covid-19-meningkat-di-bulan-juni-inialasannya-menurut-ahli?page=all

${ }^{7}$ Larassaty, Levi. 2020. Pemerintah Memberlakukan Sosial Distancing. Apa Itu Sosial Distancing ?. Diakses 10 Juli 2020 https://health.grid.id/read/352064010/pemerintah-memberlakukan-sosial-distancing-apa-itu-sosial-distancing?page=all ${ }^{8}$ Yusuf, Oik. 2020. Pandemi Covid-19 Bikin Unduhan Data Aplikasi Melonjak. Diakses 10 Juli 2020. https://tekno.kompas.com/read/2020/05/27/20030027/pandemi-covid-19-bikin-unduhan-data-aplikasi-melonjak ${ }^{9}$ Wahyudi, Reza. 2018. Riset Ungkap Pola Pemakaian Medsos Orang Indonesia. Diakses tanggal 10 Juli 2020. https://tekno.kompas.com/read/2018/03/01/10340027/riset-ungkap-pola-pemakaian-medsos-orang-indonesia?page=a
} 
Google memberikan data bahwa 50 juta jadi pengguna aktif youtube tiap minggunya dari 146 juta pengakses. Ini menandakan Youtube sebagai flatform popular ${ }^{10}$ yang senantiasa akan diakses masyarakat untuk berbagai kepentingan, mulai dari hiburan, info teknologi, perjalanan wisata, game, eksperiment, kuliner, edukasi sampai dakwah.

Youtube sebagai bagian dari New Media atau media baru yang memiliki banyak fungsi diantaranya media integrasi social. Fungsi ini dilakukan media dengan membangun kesdaran masyarakat untuk saling memiliki. ${ }^{11}$ Youtube seolah menjadi kebutuhan dan keterampilan baru yang harus dimiliki dan dipelajari. ${ }^{12}$ Namun, walaupun walaupun pada akhirnya banyak bermunculan para youtubers tapi tidak semua bisa sukses mendulang subscribers. Hal tersebut tergantung pada keterampilannya menyajikan konten menarik yang bisa menjadi video viral.

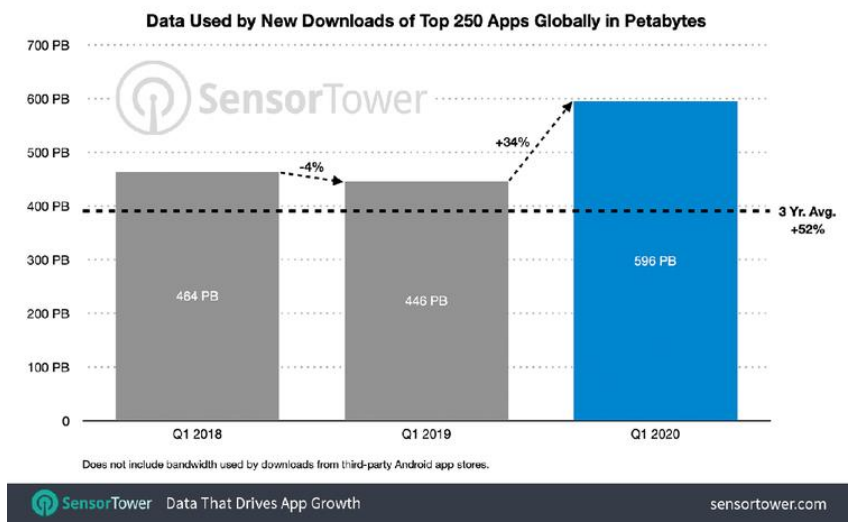

Sumber: Kompas.com - 27/05/2020

Grafik 2 Grafik perbandingan konsumsi data internet secara global untuk download 250 aplikasi terpopuler selama kuartal pertama 2018, 2019, dan 2020 menurut Sensor Tower.

Adapun sampai tahun 2019, konten video yang populer ditonton adalah video blogger keluarga. Selanjutnya dihiasi dengan konten game, musik, informasi popular, animasi, mistik tekno, kuliner, kecantikan, tips, prank dan mainan. Dapat digambarkan dengan diagram berikut.

\footnotetext{
${ }^{10}$ Cahyono, Guntur dan Nibros Hassani.2019. Youtube: Seni Komunikasi Dakwah Dan Media Pembelajaran. AL-HIKMAH: Jurnal Dakwah, Volume 13, Nomor 1, Tahun 2019[P. 023-038]

${ }^{11}$ Hajar, Ibnu. 2018. Youtube Sebagai Sarana Komunikasi Dakwah Di Kota Makassar (Analisis Sosial Media). Jurnal Al-Khitabah, Vol. V, No. 2, November $2008: 79-94$.

${ }^{12}$ Lister, Martin dan John Dovey. 2009. New Media : A New Critical Introduction. New York. Routledge
} 


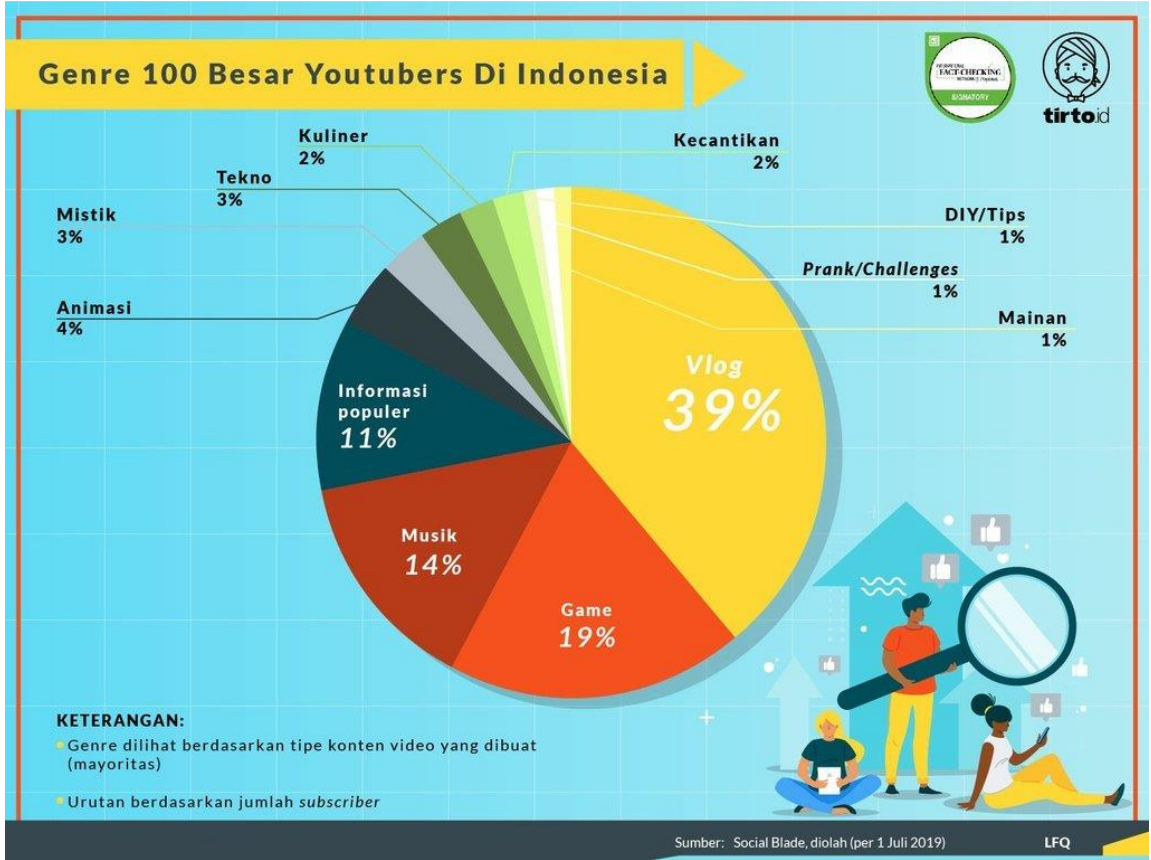

Diagram 1 Genre 100 Besar Youtubers di Indonesia 13

\section{B. Youtube Sebagai Media Sosialisasi Dakwah Masa Pandemi Covid 19}

Jika melihat diagram 1 Genre 100 Besar Youtubers di Indonesia, maka kita kan melihat bahwa konten dakwah kosong. Walaupun tidak dipungkiri ada Ustadz Youtubers yang menggarap beberapa kanal dakwah, misalnya, Ustadz Abdul Somad, Ustadz Khalid Basalamah, Ustadz Hanan Ataki, Ustadz Mustofa Bisri dan Ustadz Buya Yahya. Keberadaan dakwah Islam yang dibawakan ustadz di media sosial menjadi oase di gurun pasir.

Masa sebelum pandemi, kanal dakwah diakses hanya oleh mereka yang sibuk bekerja tapi tetap ingin mendapat siraman rohani. Atau oleh kalangan yang malu datang ke pengajian dan adapula yang ingin mendapatkan kajian Islam secara instan. Selama pandemi maka dipastikan hampir semua kalangan mengakses dakwah Islam dari media sosial. Karena atas nama sosial distancing, masyarakat tidak bisa mengakses masjid yang biasanya menyelenggarakan berbagai kajian Islam.

Peluang ini pun disambut oleh berbagai ustadz dengan melakukan dakwah dari rumah. Media Youtube tetap menjadi pilihan utama. Karena berdasarkan penelitian Youtube memberikan pengaruh signifikan dalam memperkenalkan dan memberi pengaruh positif terhadap dakwah. ${ }^{14}$ Fenomena dakwah dari rumah pun dilakukan oleh berbagai organisasi Islam. Hal ini dilakukan karena dakwah Islam adalah nyawa bagi

\footnotetext{
${ }^{13}$ Kurniawan, Frendy. 2019. Konten Paling Populer di Youtube. Diakses tanggal 10 Juli 2020. https://tirto.id/konten-paling-populer-di-youtube-indonesia-vlog-keluarga-edwU 
organisasi Islam bahkan ruh dari Islam itu sendiri.

Hamzah Sahal, aktivis media Nahdlatul Ulama dan founder alif.id mengatakan:

"Watak Islam, kan, dakwah. Ia (pendakwah) akan menggunakan sarana apapun sebagai media dakwah. Media sosial akan menjadi sarana dakwah. Bukan hanya Islam, semua agama menggunakan (sarana) apapun sebagai media dakwah." 15

Hal senada diucapkan Wasisto Raharjo Jati, peneliti Lembaga Ilmu Pengetahuan Indonesia. Tiga tahun terakhir, Wasisto menekuni fenomena kebangkitan kelas menengah Muslim di Indonesia. "Itu (dakwah lewat media sosial) adalah dakwah agama yang mengggunakan media baru untuk menyampaikan ajaran agama." 16

Kebangkitan dakwah di media sosial adalah kemajuan bagi dakwah Islam. Karena pada hakikatnya dengan atau tanpa media sosial, dakwah harus terus berjalan. Media sosial hanya sarana yang mampu mempercepat penyebaran dakwah Islam. Hal ini karena dorongan dakwah bukanlah materi melainkan keimanan dan ketaqwaan kepada Allah.

Dalam al Quran surat Ali Imran ayat 110, Allah berfirman:

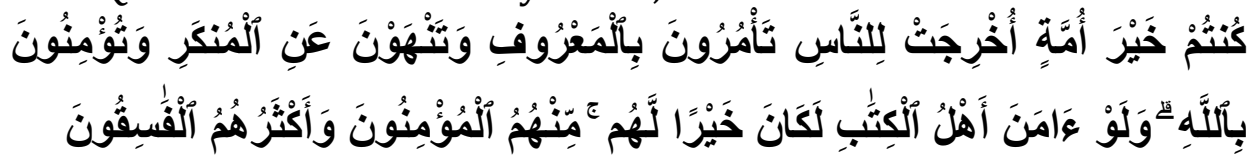

Kamu adalah umat yang terbaik yang dilahirkan untuk manusia, menyuruh kepada yang ma'ruf, dan mencegah dari yang munkar, dan beriman kepada Allah. Sekiranya Ahli Kitab beriman, tentulah itu lebih baik bagi mereka, di antara mereka ada yang beriman, dan kebanyakan mereka adalah orang-orang yang fasik.

Ayat diatas mengandung perintah dakwah yang bersifat wajib karena mengandung pujian bagi umat yang melaksanakannya sebagian umat terbaik. Bahkan Allah menyematkan pujian kepada aktifitas dakwah itu sendiri sebagai ucapan yang lebih baik. Allah berfirman dalam al-Quran surat Fushilat ayat 33 :

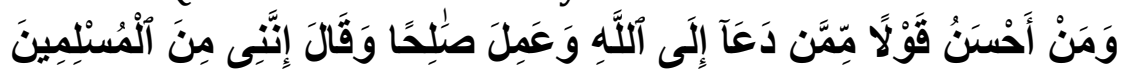

Siapakah yang lebih baik perkataannya daripada orang yang menyeru kepada Allah, mengerjakan amal yang saleh, dan berkata: "Sesungguhnya aku termasuk orang-orang yang menyerah diri?"

Begitupun bagi para pengemban dakwah Allah lebih mereka derajatnya. Karena

\footnotetext{
${ }^{15}$ Zaenudin, Ahmad. 2017. Mengapa Para Dai Bisa Amat Populer di Media Sosial? https://tirto.id/mengapa-para-dai-bisa-amat-populer-di-media-sosial-cCox 
sesungguhya aktifitas dakwah bagian dari jihad fi sabilillah. Sebagaimana Allah jelaskan dalam al-Quran surat an-Nisa' ayat 95 :

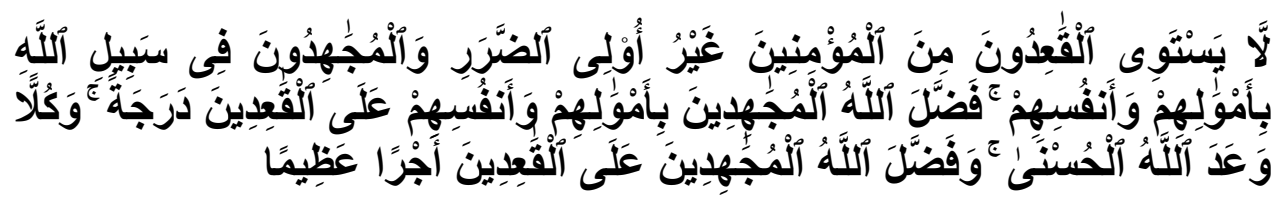

Tidaklah sama antara mukmin yang duduk (yang tidak ikut berperang) yang tidak mempunyai 'uzur dengan orang-orang yang berjihad di jalan Allah dengan harta mereka dan jiwanya. Allah melebihkan orang-orang yang berjihad dengan harta dan jiwanya atas orang-orang yang duduk satu derajat. Kepada masing-masing mereka Allah menjanjikan pahala yang baik (surga) dan Allah melebihkan orang-orang yang berjihad atas orang yang duduk dengan pahala yang besar,

Maka menjadi sebuah kewajiban dakwah Islam terus diaruskan secara masif terutama masa pandemic Covid 19. Baik dilakukan oleh individu maupun jamaah (komunitas). Namun, jika dakwan dilakukan individu tentu frekuensi akan lebih terbatas jika dibandingkan dengan dilakukan oleh organisasi dakwah. Karena organisasi dakwah punya kader yang menjadi sumber daya manusia, punya jaringan luas dan dukungan kompetensi dari sumber daya yang dimiliki.

Seperti yang dilakukan oleh kanal Youtube Muslimah Media Center. Dalam pengamatan peneliti, mereka melakukan dakwah Islam dengan beragam konten mulai dari politik, ekonomi, social, pendidikan sampai remaja. Dakwah mereka terlihat dilakukan secara massif mulai masa pandemic Covid 19. Dalam sehari mereka bisa posting video 4 kali. Mulai dari jam 06.00, kemudian jam 12.00, jam 18.00 dan terakhir jam 21.00. Ini jarang bahkan tidak dilakukan oleh kanal dakwah lain. Ini menunjukkan bahwa mereka menjadikan Youtube sebagai media utama dalam sosialisasi dakwah Islam.

\section{Analisis Konten Dakwah Kanal Youtube Muslimah Media Center}

Muslimah Media Center adalah salah satu kanal dakwah di Youtube yang dirintis dari halaman Facebook tanggal 30 Mei 2016. Memiliki moto "Insprasi Muslimah Masa Kini". Channel Muslimah Media Center bisa diakses dengan alamat https://www.youtube.com/channel/UCgQBZ25YtD cm8hpCsey67w/. Adapun sasaran penggemarnya yaitu remaja, ibu dan perempuan. Total yang menyukai kanal ini adalah 12.101. Sedangkan, pengikutnya mencapai 12.788 . 
YOUTUBE SEBAGAI MEDIA DAKWAH MASA PANDEMI COVID 19

(Studi Analisis Konten Dakwah Channel Muslimah Media Center 15-30 Juni 2020)

Peneliti mengumpulkan dan mengklasifikasikan video yang diposting di Youtube oleh Muslimah Media Center dari tanggal 15-30 Juni 2020 sebagai berikut:

\begin{tabular}{|c|c|c|c|c|c|c|c|c|}
\hline$\overline{\text { Tggl }}$ & $\begin{array}{l}\text { One Minute } \\
\text { Booster Extra }\end{array}$ & MMC Video & Serba-serbi MMC & $\begin{array}{c}\text { MMC } \\
\text { Millenials }\end{array}$ & Analisis & $\begin{array}{l}\text { Podcast } \\
\text { MMC }\end{array}$ & Sejarah Islam & Blusukan \\
\hline 15 & & $\begin{array}{l}\text { KDRT Meningkat di } \\
\text { Masa Pandemi, Negara } \\
\text { Harus Tanggung Jawab }\end{array}$ & $\begin{array}{l}\text { Kalian Jangan Cuek } \\
\text { Trending!!! }\end{array}$ & - & $\begin{array}{l}\text { Silang } \\
\text { Sengkar } \\
\text { ut } \\
\text { BUMN }\end{array}$ & $\begin{array}{l}\text { SILANG } \\
\text { SENGKARUT } \\
\text { BUMN - Seg. } \\
2 \text { Eps. } 3\end{array}$ & & \\
\hline 16 & $\begin{array}{l}\text { Keikhlasan } \\
\text { Pengemban } \\
\text { Dakwah } \\
\text { Menentukan } \\
\text { Kualitas Amal }\end{array}$ & $\begin{array}{l}\text { Pemerintah Tidak } \\
\text { Serius, Pariwisata } \\
\text { Dibuka di Masa } \\
\text { Pandemi }\end{array}$ & $\begin{array}{l}\text { Gaji ke-13! Kalo } \\
\text { Jadi Cair, } \\
\text { "Kapan"??? }\end{array}$ & $\begin{array}{l}\text { Gosipin } \\
\text { Artis, Kok } \\
\text { Enak Ya??? }\end{array}$ & & $\begin{array}{l}\text { Bagaimanak } \\
\text { ah } \\
\text { Menyikapi } \\
\text { Penguasa } \\
\text { yang Gemar } \\
\text { Maksiat? }\end{array}$ & & \\
\hline 17 & $\begin{array}{l}\text { Inilah Hal yang } \\
\text { Dapat } \\
\text { Menghancurkan } \\
\text { Ibadah }\end{array}$ & $\begin{array}{l}\text { Kok Pembayaran Gaji } \\
\text { Ditunda? }\end{array}$ & & & & & $\begin{array}{l}\text { Kerasnya } \\
\text { Halangan } \\
\text { Hijrah Kaum } \\
\text { Muslimin ke } \\
\text { Makkah }\end{array}$ & $\begin{array}{l}\text { Suasana } \\
\text { New Normal } \\
\text { di Berbagai } \\
\text { Daerah } \\
\text { Disambut } \\
\text { Hangat?? }\end{array}$ \\
\hline 18 & $\begin{array}{l}\text { Syarat } \\
\text { Diterimanya } \\
\text { Ibadah }\end{array}$ & $\begin{array}{l}\text { Harga Minyak Dunia } \\
\text { Anjlok, Apa Kabar } \\
\text { Dunia? }\end{array}$ & $\begin{array}{l}\text { Indonesia Penuhi } \\
\text { Empat Kriteria } \\
\text { Negara Otoriter? }\end{array}$ & $\begin{array}{l}\text { "Generasi } \\
\text { Unfaedah" }\end{array}$ & & & & \\
\hline 19 & $\begin{array}{l}\text { Ikhlas Adalah } \\
\text { Amalan Hati yang } \\
\text { Tersembunyi }\end{array}$ & $\begin{array}{l}\text { Khilafah Menjamin } \\
\text { Tidak Adanya } \\
\text { Otoritarianisme }\end{array}$ & $\begin{array}{l}\text { APD Dulunya } \\
\text { Dicari, Sekarang } \\
\text { Dikirim Keluar } \\
\text { Negeri? }\end{array}$ & $\begin{array}{l}\text { Untuk Kamu } \\
\text { yang Merasa } \\
\text { Insecure }\end{array}$ & & $\begin{array}{l}\text { Refleksi } \\
\text { Tauhid } \\
\text { Untuk } \\
\text { Kontrol dan } \\
\text { Kendali Diri }\end{array}$ & & \\
\hline 20 & $\begin{array}{l}\text { Sirah Rasulullah } \\
\text { Bukan Sekedar } \\
\text { Rangkaian Sejarah }\end{array}$ & $\begin{array}{l}\text { Wacana Khilafah-isme } \\
\text { adalah Upaya } \\
\text { Mendistorsi Ajaran } \\
\text { Islam }\end{array}$ & $\begin{array}{l}\text { The Great } \\
\text { Lockdown: Resesi } \\
\text { Terparah. Masih } \\
\text { Sempat revisi 4\%, } \\
\text { 2,3\% Hingga 1\% } \\
\text { ??? }\end{array}$ & $\begin{array}{l}\text { New } \\
\text { Normal, } \\
\text { New Me !!! }\end{array}$ & & & & \\
\hline 21 & $\begin{array}{l}\text { Menghindari } \\
\text { Kesombongan } \\
\text { Bukan Berarti } \\
\text { Menghindari } \\
\text { Punya Kelebihan }\end{array}$ & $\begin{array}{l}\text { Perlukah Sistem } \\
\text { Alternatif dalam } \\
\text { Menangani Pandemi? }\end{array}$ & & & & & $\begin{array}{l}\text { Mengapa } 1 \\
\text { Muharram } \\
\text { Dijadikan } \\
\text { Tahun Baru } \\
\text { Hijriyah? }\end{array}$ & $\begin{array}{l}\text { Semangat } \\
\text { Belajar } \\
\text { Daring } \\
\text { Meski } \\
\text { Kadang } \\
\text { Bikin Bosen }\end{array}$ \\
\hline 22 & $\begin{array}{l}\text { Antara Riya' dan } \\
\text { Keikhlasan dalam } \\
\text { Ketaatan }\end{array}$ & $\begin{array}{l}\text { Sekolah Zona Hijau } \\
\text { Dibuka? }\end{array}$ & $\begin{array}{l}\text { Negara-negara } \\
\text { Stop Ekspor } \\
\text { Pangan, } \\
\text { Bagaimana Nasib } \\
\text { Indonesia }\end{array}$ & $\begin{array}{l}\text { Aku Jatuh } \\
\text { Cinta } \\
\text { Kepada } \\
\text { Dirinya }\end{array}$ & & & & \\
\hline 23 & $\begin{array}{l}\text { Keikhlasan } \\
\text { Pengemban } \\
\text { Dakwah } \\
\text { Menentukan } \\
\text { Kualitas Amal } \\
\text { Berbahagialah } \\
\text { Menjadi Ghuroba' }\end{array}$ & $\begin{array}{l}\text { Krisis Pangan! Ekspor } \\
\text { Pangan Berhenti? }\end{array}$ & $\begin{array}{l}\text { Sekali Tes Covid } \\
\text { 19 Sampai Jutaan } \\
\text { Rupiah, Upaya } \\
\text { Pemerasan??? }\end{array}$ & & & & $\begin{array}{l}\text { Membangun } \\
\text { Batu Pondasi } \\
\text { Negara Islam } \\
\text { Pertama }\end{array}$ & \\
\hline 24 & $\begin{array}{l}\text { Dakwah Bukan } \\
\text { Hanya Tentang } \\
\text { Kepiawaian }\end{array}$ & $\begin{array}{l}\text { 'Rapid Test' Gratis } \\
\text { Sepanjang Masa }\end{array}$ & & $\begin{array}{l}\text { Terjebak } \\
\text { Masalah! }\end{array}$ & & & & $\begin{array}{l}\text { Diserbu } \\
\text { Orang Minta } \\
\text { Duit dan } \\
\text { Sembako..?? }\end{array}$ \\
\hline 25 & $\begin{array}{l}\text { Inilah Aktivitas } \\
\text { yang } \\
\text { Kedudukannya } \\
\text { Sangat Tinggi }\end{array}$ & $\begin{array}{l}\text { Mahasiswa: Turunkan } \\
\text { UKT! }\end{array}$ & $\begin{array}{l}\text { PPDB 2020: Ortu } \\
\text { Protes PPDB } \\
\text { Zonasi } \\
\text { Pertimbangkan } \\
\text { Umur }\end{array}$ & & & $\begin{array}{l}\text { Ngomong } \\
\text { Politik \#4 - } \\
\text { New Normal } \\
\text { Jilid 3??? }\end{array}$ & & \\
\hline 26 & & $\begin{array}{l}\text { Polemik Syarat Usia } \\
\text { PPDB Jakarta Menuai } \\
\text { Demo Orang Tua Calon } \\
\text { Siswa }\end{array}$ & & $\begin{array}{l}\text { Kok Capek } \\
\text { Banget Sih } \\
\text { Mau Belajar }\end{array}$ & & $\begin{array}{l}\text { Ngomong } \\
\text { Politik \#5 - } \\
\text { Pajak }\end{array}$ & & \\
\hline
\end{tabular}




\begin{tabular}{|c|c|c|c|c|c|c|c|c|}
\hline & & & & & & $\begin{array}{l}\text { Ataukah } \\
\text { Palak??? }\end{array}$ & & \\
\hline \multirow[t]{4}{*}{27} & Mengapa Umat & UU Minerba Bentuk & Kartu Pra-kerja, & & & Corona dan & Masjid Nabawi? & \\
\hline & Butuh Dakwah? & Tidak Peka Penguasa & "Kartu Sakti" & & & Konspirasi & Inilah Fungsi & \\
\hline & & Saat Pandemi & Iming-iming & & & & Awal & \\
\hline & & & Rakyat? & & & & Dibangunnya & \\
\hline \multirow[t]{4}{*}{28} & Perjuangan & Kartu Prakerja & & Untuk Kamu & Pajak & & & Kaya Praktis \\
\hline & Dakwah untuk & Bermasalah Lagi, KPK & & yang Merasa & Ataukah & & & Modal SMS \\
\hline & Kemurnian Islam & Temukan 4 & & Insecure & Palak? & & & \\
\hline & & Kejanggalan & & & & & & \\
\hline \multirow[t]{3}{*}{29} & Dakwah Menjamin & Tes Masif Covid-19, & Utang Negara & Dilema & & & & \\
\hline & Keberlangsungan & Kasus Tembus & Tembus Rp & Content & & & & \\
\hline & Islam & $\begin{array}{l}\text { 1000/hari, } \\
\text { Keberhasilan?? }\end{array}$ & 5.258,57 Triliun!!! & Creator & & & & \\
\hline \multirow[t]{5}{*}{30} & Inilah & Utang demi Corona? & Dana Fantastis, & Rebahan & & Refleksi & & \\
\hline & Perumpamaan & Benarkah? & Pilkada 2020 & Sambil Nge- & & Tauhid & & \\
\hline & Bagi Orang-Orang & & Ngotot Tetap & Game Aja & & Untuk & & \\
\hline & yang Amar Ma'ruf & & Ada!!! & $\mathrm{Ah} !$ & & Kontrol dan & & \\
\hline & Nahi Munkar[ & & & & & Kendali Diri & & \\
\hline
\end{tabular}

Tabel 1. Klasifikasi video yang diposting kanal Youtube

Muslimah Media Center 15-30 Juni $2020^{17}$

Dari tabel diatas dapat difahami bahwa dalam satu hari kanal Youtube Muslimah Media Center (MMC) mengunggah 4-5 video dengan jam posting yang cukup rapi yaitu jam 04.00, 07.00, 16.00, 22.00. Berarti ini bukan pekerjaan individu tapi pekerjaan tim penuh misi. Hal ini tidak dilakukan oleh youtubers lainnya.

Peneliti melihat MMC sudah mengklasifikasi menu video unggahan. Mulai dari One Minute Booster Extra, MMC Video, Serba serbi MMC, MMC Milenial, Analisis, Podcast MMC, Sejarah Islam dan Blusukan. Setiap menu punya kekhasan konten.

One minute booster dari MMC menyajikan konten motivasi aqidah, ibadah dan dakwah. Konten motivasi dakwah lebih mendominasi. MMC mengajak penggemar untuk menyadari bahwa dakwah adalah kewajiban setiap muslim. Banyak perintah Allah yang tegas untuk melakukannya. Allah juga menjanjikan kedudukan mulia bagi para pengembannya. Konten Dakwah yang disajikan MMC memiliki sudut pandang yang berbeda dari kanal dakwah lainnya. Karena memandang dakwah sebagai aktifitas yang tidak terbatas pada mengisi ta'lim yang hanya bisa dilakukan ulama. Tapi mereka memahamkan ummat bahwa ketika memahami satu hukum Allah kemudian disampaikan itu adalah bagian dari dakwah.

Menu MMC Video menyajikan ulasan fakta, analisis solusi dari isu nasional yang sedang up date. Analisisnya cukup mencerdaskan. Solusinya selalu MMC dasarkan pada sumber hukum Islam. Konten seperti ini jarang diangkat oleh kanal dakwah lain.

Menu Serba Serbi MMC hampir sama dari sisi konten dengan MMC Video. Yaitu, menyajikan fakta, analisis dan solusi Islam atas permasalahan yang sedang mencuat di

\footnotetext{
${ }^{17}$ Facebook Muslimah Media Center. https://www.facebook.com/pg/MuslimahMediaCenter/posts/?ref=page internal
} 
Indonesia. Namun, bahasa yang dipakai adalah bahasa yang lebih sederhana. Bahasa masyarakat umum. Konten seperti ini sulit ditemukan di kanal dakwah lain.

MMC Milenial adalah menu video untuk kalangan remaja. Tema yang diangkat adalah tema khas remaja dan dengan bahasa yang disesuaikan dengan istilah-istilah gaul remaja. Sehingga, ketika mendengar judulnya pun, remaja tahu itu sajian untuk mereka. Konten ini pun jarang ditemui pada kanal dakwah lain.

Menu analisis pada kanal MMC juga sangat jarang disajikan kanal lain. Menu analisis didominasi oleh tema ekonomi. Tentunya menghadirkan analisis fakta dan solusi yang memuaskan karena diambil dari pakar.

Podcast MMC adalah menu dalam kanal MMC yang ditampilkan dalam forum diskusi santai terhadap permasalahan hangat di Indonesia. Peneliti melihat podcast lebih banyak mengemukakan sikap yang harus diambil seorang muslim ketika menghadapi permasalahan di negaranya. Podcast ini menghadirkan narasumber mubalighoh maupun pakar perempuan.

Sejarah Islam adalah menu dalam kanal dakwah MMC yang tidak terlalu banyak muncul. Ketika pun ada, kajiannya tidak jauh berbeda dengan kajian kanal dakwah lain terkait sejarah Islam. Namun, tetap menampilkan sudut analisis dan pelajaran yang sedikit berbeda.

Blusukan adalah menu dalam kanal dakwah MMC yang khas mengangkat tema tema update yang dikemas dengan wawancara di kampus-kampus atau di sekolahsekolah bahkan di pemukiman warga. Ini sangat khas yang jarang peneliti temukan pada kanal dakwah lain.

Dari keseluruhan konten yang diangkat, MMC ingin melakukan penyadaran umat terhadap berbagai permasalahn yang terjadi di negara kita. Jangan sampai kita menjadi umat yang tidak peduli dan mementingkan kehidupan pribadi diatas kepentingan umat. Dari berbagai analisis dan solusi yang disampaikan, MMC sepertinya ingin membangun kerangka berpikir Islam. Yaitu kerangka berpikir yang selalu berpusat pada Islam sebagai sumber hukum, standar hukum dan sumber solusi bagi segala permasalahan umat. Bahkan menyerukan agar syariat Islam ditegakkan baik di Indonesia maupun di dunia melalui institusi bersistem atau berideologi Islam.

Jika kita bandingkan dengan kanal dakwah lain, maka kita kan menemukan perbedaan kerangka berpikir yang signifikan. Bahwa yang sering kita dapatkan dari kanal dakwah lain adalah Islam sebagai sumber hukum. Jika sudah membahas ini ayatnya ini haditsnya maka masalah selesai. Tidak memunculkan seperti yang dimunculkan MMC yaitu bahwa Islam sebagai sumber hukum dan Islam sebagai sistem hidup yang wajib diterapkan karena permasalahan akan tuntas jika semua masalah diselesaikan sesuai dengan hukum Islam dan didukung oleh sistem kehidupan Islam. 
Konten dakwah MMC secara umum aman dari perdebatan golongan. Karena konten dakwah MMC tidak berisi masalah fikih yang mungkin tiap madzhab berbeda. Namun, bisa jadi mendapat perhatian khusus dari pemerintah. Karena secara lembut menggiring opini publik ${ }^{18}$ yang pada dasarnya dikhawatirkan pemerintah.

Jika dihubungkan dengan sasaran penggemarnya yaitu perempuan, ibu dan remaja, maka MMC ingin membangun sebuah brand bagi muslimah bahwa mereka bukan saja harus berkutat dalan urusan rumah tangga. Tapi juga ikut memikirkan nasib bangsa dengan turut memberikan masukan bagi pemerintah dalam mengatasi permasalahan bangsa.

\section{KESIMPULAN}

Pendemi Covid 19 tidak membuat dakwah terhenti karena perkembangan teknologi media sosial menyediakan berbagai aplikasi. Youtube sebagai aplikasi media social yang paling banyak diakses menjadi peluang besar. Hal ini disadari oleh berbagai kanal dakwah Youtube termasuk kanal dakwah Muslimah Media Center (MMC). Adapun konten dakwah MMC sangat produktif dan unik. Produktif karena selain frekuensi posting yang tinggi setiap hari, juga mengangkat tema-tema dari masalah yang sedang hangat. Baik tentang politik, ekonomi, social, kesehatan terutama penanganan pandemic covid 19, pendidikan maupun remaja. Konten disajikan dengan sebuah kerangka berpikir bahwa berbagai permasalahan yang terjadi akibat pengaturan kapitalisme yang keliru. Selalu diakhiri dengan seruan untuk kembali pada aturan atau sistem atau ideology Islam sebagai solusi bagi setiap permasalahan.

${ }^{18}$ Arifin, Ferdi. 2019. Mubalig Youtube Dan Komodifikasi Konten Dakwah. Al-Balagh: Jurnal Dakwah dan Komunikasi. Vol. 4, No. 1 , January - June 2019, pp. 91 - 120, DOI: 10.22515/balagh.v4i1.1718 ISSN: 2527-5704 (P) ISSN: 2527-5682 (E) 


\section{Sumber Jurnal}

\section{DAFTAR PUSTAKA}

Arifin, Ferdi. 2019. Mubalig Youtube Dan Komodifikasi Konten Dakwah. Al-Balagh: Jurnal Dakwah dan Komunikasi. Vol. 4, No. 1, January - June 2019, pp. 91 - 120, DOI: 10.22515/balagh.v4i1.1718 ISSN: 2527-5704 (P) ISSN: 2527-5682 (E) Cahyono, Guntur dan Nibros Hassani.2019. Youtube: Seni Komunikasi Dakwah Dan Media Pembelajaran. AL-HIKMAH: Jurnal Dakwah, Volume 13, Nomor 1, Tahun 2019[P. 023-038]

Hajar, Ibnu. 2018. Youtube Sebagai Sarana Komunikasi Dakwah Di Kota Makassar (Analisis Sosial Media). Jurnal Al-Khitabah, Vol. V, No. 2, November 2008 : 79 - 94.

Lister, Martin dan John Dovey. 2009. New Media : A New Critical Introduction. New York. Routledge

Ramadhan, Randy dan Henny Destiana. Pengaruh Media Sosial Youtube terhadap Perkembangan Dakwah Islam dengan Metode Structural Equation Modeling(SEM). Sinkron: Jurnal \& Penelitian Teknik Informatika Volume 1 Nomor3, Oktober 2018

Sofiyanti, Aulya dan Mada Wijaya Kusumah, 2020, Pemanfaatan Media Dakwah yang Efektif di Tengah Pandemi Covid 19, Prosiding Seminar Nasional Online "Dakwah di Masa Pandemi Covid-19", Sukabumi : Program Studi Komunikasi dan Penyiaran Islam STIBA Ar-Raayah.

\section{Sumber Buku}

Lister, Martin dan John Dovey. 2009. New Media : A New Critical Introduction. New York. Routledge

Uwaidah, Mahmud Abdul Latif. 2003. Pengemban Dakwah, Kewajiban dan Sifat-sifatnya. Bogor, Pustaka Thariqul Izzah.

\section{Sumber di Luar Jurnal dan Buku}

Azanella, Luthfia Ayu. 2020. Tren Kasus Covid 19 Meningkat di Buan Juni, Ini Aklasannya Menurut Ahli . Diakses 10 Juli 2020.

https://www.kompas.com/tren/read/2020/06/17/200500665/tren-kasuscovid-19-meningkat-di-bulan-juni-ini-alasannya-menurut-ahli?page=all.

Facebook Muslimah Media Center. Diakses tanggal 10 Juli 2020. https://www.facebook.com/pg/MuslimahMediaCenter/posts/?ref=page internal

Kurniawan, Frendy. 2019. Konten Paling Populer di Youtube. Diakses tanggal 10 Juli 2020. https://tirto.id/konten-paling-populer-di-youtube-indonesia-vlogkeluarga-edwU

Larassaty, Levi. 2020. Pemerintah Memberlakukan Sosial Distancing. Apa Itu Sosial Distancing? , diakses 10 Juli 2020.

https://health.grid.id/read/352064010/pemerintah-memberlakukan-sosialdistancing-apa-itu-sosial-distancing?page=all

Widyananda, Rakha Fahreza. 2020. Macam Media Sosial yang Paling Sering Digunakan Oleh Orang Indonesia. Diakses 10 Juli 2020. https://www.merdeka.com/jatim/10macam-media-sosial-yang-paling-sering-digunakan-oleh-orang-indonesia-kln.html 
YOUTUBE SEBAGAI MEDIA DAKWAH MASA PANDEMI COVID 19

(Studi Analisis Konten Dakwah Channel Muslimah Media Center 15-30 Juni 2020)

Youtube Muslimah Media Center. Diakses tanggal 10 Juli 2020. https://www.youtube.com/c/MUSLIMAHMEDIACENTERID/about

Yusuf, Oik. 2020. Pandemi Covid-19 Bikin Unduhan Data Aplikasi Melonjak. Diakses 10 Juli 2020. https://tekno.kompas.com/read/2020/05/27/20030027/pandemicovid-19-bikin-unduhan-data-aplikasi-melonjak

Zaenudin, Ahmad. 2017. Mengapa Para Dai Bisa Amat Populer di Media Sosial? https://tirto.id/mengapa-para-dai-bisa-amat-populer-di-media-sosial-cCox 